\title{
Sulindac enhances arsenic trioxide-mediated apoptosis by inhibition of NF- $\kappa$ B in HCT116 colon cancer cells
}

\author{
HYE RAN LEE ${ }^{1 *}$, HEE-JEONG CHEONG ${ }^{2,3 *}$, SOOK-JA KIM ${ }^{2,3}$, \\ NAM-SU LEE ${ }^{2,3}$, HEE-SOOK PARK ${ }^{2,3}$ and JONG-HO WON ${ }^{2,3}$ \\ ${ }^{1}$ Department of Internal Medicine, Inje University, Ilsan Paik Hospital; ${ }^{2}$ Division of Hematology-Oncology, \\ ${ }^{3}$ Institute for Clinical Molecular Biology Research, Soon Chun Hyang University College of Medicine, Seoul, Korea
}

Received February 5, 2008; Accepted April 2, 2008

\begin{abstract}
To study whether the apoptotic effect of arsenic trioxide $\left(\mathrm{As}_{2} \mathrm{O}_{3}\right)$ on colon cancer cells could be enhanced by the addition of sulindac, HCT116 cells were treated with $\mathrm{As}_{2} \mathrm{O}_{3}(1,5,10 \mu \mathrm{M})$ and sulindac $(0.5 \mathrm{mM})$, either alone or in combination. $\mathrm{As}_{2} \mathrm{O}_{3}$ alone slightly inhibited the growth of HCT116 cells, whereas the combination of $\mathrm{As}_{2} \mathrm{O}_{3}$ and sulindac reduced cell growth by $30-40 \%$. Annexin V staining indicated that the synergistic effect of the combination was mediated through increased apoptosis. We examined whether the combination of $\mathrm{As}_{2} \mathrm{O}_{3}$ and sulindac on apoptosis is mediated by inhibition of the $\mathrm{NF}-\kappa \mathrm{B}$ pathway in HCT116 colon cancer cells. Western blot analysis showed that the level of nuclear NF-кB (p65) was not changed significantly by $\mathrm{As}_{2} \mathrm{O}_{3}$ or sulindac treatment alone, while the level of nuclear NF-кB (p65) was drastically decreased in the combination treatment by inhibiting the phosphorylation and the degradation of IкB- $\alpha$. These results suggest that sulindac enhances apoptosis when combined with $\mathrm{As}_{2} \mathrm{O}_{3}$ by inhibiting $\mathrm{NF}-\kappa \mathrm{B}$ activation mediated through the blocking of phosphorylation and degradation of IкB- $\alpha$.
\end{abstract}

\section{Introduction}

During the last decade, arsenic trioxide $\left(\mathrm{As}_{2} \mathrm{O}_{3}\right)$ has been proven to be a promising alternative treatment in relapsed

Correspondence to: Dr Jong-Ho Won, Division of HematologyOncology and Institute for Clinical Molecular Biology Research, Soon Chun Hyang University College of Medicine, 657 Hannamdong, Yongsan-gu, Seoul 140-743, Korea

E-mail: jhwon@hosp.sch.ac.kr

${ }^{*}$ Contributed equally

Abbreviations: APL, acute promyelocytic leukemia; NSAID, nonsteroidal anti-inflammatory drug; NF- $\mathrm{KB}$, nuclear factor- $\mathrm{\kappa B}$

Key words: arsenic trioxide, sulindac, apoptosis, NF-кB, colon cancer cells patients with acute promyelocytic leukemia (APL) as well as newly diagnosed APL patients. Even in relapsed APL patients, complete remission rates have reached $80-100 \%$ (1). Moreover, toxicities do not seem to be serious with only minimal myelosuppression. The most common side effects of $\mathrm{As}_{2} \mathrm{O}_{3}$ were gastrointestinal symptoms. The mechanisms of action were shown to exert dose-dependent dual effects in APL cells, i.e., by triggering apoptosis and inducing partial differentiation $(2,3)$. This promotes differentiation of APL cells at low concentrations, however at high concentrations, it triggers apoptosis and inhibits the growth of cells. These effects were associated with the modulation and degradation of the $\mathrm{t}(15 ; 17)$-specific fusion protein PML-RAR $\alpha(4,5)$. Recent studies show that the apoptotic effect of $\mathrm{As}_{2} \mathrm{O}_{3}$ is not specific to APL cells, and that it can be observed in non-APL leukemia and lymphoma cells, as well as in other solid tumor cell lines (6-9). Antitumor effects may be enhanced when $\mathrm{As}_{2} \mathrm{O}_{3}$ is combined with other agents such as all-transretinoic acid (ATRA) and interferon- $\alpha$ (IFN- $\alpha)$. These drugs have been reported to synergistically promote apoptosis when combined with $\mathrm{As}_{2} \mathrm{O}_{3}(10,11)$. The mechanism of $\mathrm{As}_{2} \mathrm{O}_{3}$ for inducing apoptosis is explained by the activation of caspases, the downregulation of Bcl-2 and the modulation of p53, as well as the uncoupling of the mitochondrial potential (12-14).

A transcriptional factor, NF- $\mathrm{NB}$ is known to induce genes that promote cell survival and block apoptosis. In addition, $\mathrm{NF}-\kappa \mathrm{B}$ can upregulate genes which are significant in tumor growth and metastasis (15). Sulindac (nonsteroidal antiinflammatory drug, NSAID) may cause regression of colonic polyps and block their progression to cancer. Sulindac and its metabolites are known to inhibit the $\mathrm{NF}-\kappa \mathrm{B}$ pathway $(16,17)$. According to Berman et al, sulindac enhances tumor necrotic factor (TNF)-mediated apoptosis in lung carcinoma by suppressing NF-кB (15). This suggests that sulindac and other NSAIDs may serve as useful agents in cancer chemotherapy.

To find out whether the apoptotic effect of $\mathrm{As}_{2} \mathrm{O}_{3}$ on colon cancer cells could be enhanced by the addition of sulindac, HCT116 cells were treated with $\mathrm{As}_{2} \mathrm{O}_{3}$ and sulindac, either alone or in combination. In addition, our study revealed that this synergistic effect was mediated by inhibition of the $\mathrm{NF}-\kappa \mathrm{B}$ pathway in HCT116 colon cancer cells. 


\section{Materials and methods}

Cell cultures and reagents. HCT116 human colon cancer cell line was obtained from the American Type Culture Collection (ATCC; Manassas, VA, USA) and grown in MacCoy's 5A medium (Gibco, Rockville, NY, USA) supplemented with $10 \%$ fetal bovine serum (FBS; Gibco) in a humidified $5 \%$ carbon dioxide and $95 \%$ air incubator at $37^{\circ} \mathrm{C}$. Sulindac and $\mathrm{As}_{2} \mathrm{O}_{3}$ were obtained from Sigma (St. Louis, MO, USA). Sulindac was dissolved in methanol at a concentration of $100 \mathrm{mM}$ stock solution and $\mathrm{As}_{2} \mathrm{O}_{3}$ was dissolved in $\mathrm{NaOH}$. All chemicals were obtained from Sigma, unless otherwise stated.

Antibodies. The rabbit anti-active caspase-3, rabbit anticaspase- 8 , mouse anti-IкB- $\alpha$ phospho-specific, mouse anti-

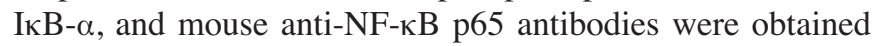
from BD Pharmingen (Mountain View, CA, USA).

Cell viability assays. Cell viability was assessed by MTT assay kit (Roche, Mannheim, Germany). MTT assays were used to measure the number of viable cells. In this assay, the membrane permeant dye is reduced by mitochondrial reductases in living cells, and spectrophotometric measurement allows quantification of cell viability. Equal numbers of cells were cultured in 96-well plates. HCT116 colon cancer cells were pretreated for $2 \mathrm{~h}$ with or without $0.5 \mathrm{mM}$ sulindac, and $\mathrm{As}_{2} \mathrm{O}_{3}(1,5,10 \mu \mathrm{M})$ were treated. Twenty-four hours after adding $\mathrm{As}_{2} \mathrm{O}_{3}, 10 \mu \mathrm{l}$ of the MTT labeling reagent was added to the cultured medium. Cells were incubated for $4 \mathrm{~h}$ at $37^{\circ} \mathrm{C}$ and then a $100 \mu 1$ solubilization solution was added to the cultured medium to dissolve the formazan crystals. The absorbance was then measured at a wave length of $562 \mathrm{~nm}$ on an ELISA reader after $24 \mathrm{~h}$.

Wright staining. HCT116 colon cancer cells were pretreated for $2 \mathrm{~h}$ with or without $0.5 \mathrm{mM}$ sulindac, and then treated for $24 \mathrm{~h}$ with $\mathrm{As}_{2} \mathrm{O}_{3}(1,5,10 \mu \mathrm{M})$. The cells $\left(1 \times 10^{5}\right)$ were spun (Shandon Cytospin 4; Thermo Electron Co., Pittsburgh, PA, USA) on the silane coated slides (Dako) for $5 \mathrm{~min}$ at $500 \mathrm{rpm}$. After the slides were air-dried and Wright stained, coverslips were mounted and examined with a microscope.

Annexin V-fluorescein staining. HCT116 colon cancer cells were pretreated for $2 \mathrm{~h}$ with or without $0.5 \mathrm{mM}$ sulindac, and then treated for $24 \mathrm{~h}$ with $\mathrm{As}_{2} \mathrm{O}_{3}(1,5,10 \mu \mathrm{M})$. Following the manufacturer's protocol (Annexin-V-FLUOS Staining Kit; Roche), $1 \times 10^{6}$ cells were washed twice with phosphate buffered saline (PBS; Gibco) and incubated with fluorescein isothiocyanate (FITC)-conjugated annexin-V at room temperature for $15 \mathrm{~min}$ in the dark. The cells were then analyzed by flow cytometry (FACScan; Becton Dickinson, San Diego, CA, USA) using a single laser emitting excitation light at $515 \mathrm{~nm}$.

Western blot analysis. Total cellular proteins for measuring caspase-3, and -8 activation or nuclear and cytoplasmic extracts for measuring NF-кB, p65 and IкB- $\alpha$ levels, equal amounts of protein $(20 \mu \mathrm{g} /$ lane $)$ were separated by $10 \%$ SDS-PAGE (polyacrylamide gel electrophoresis) and the proteins were electrophoretically transferred to a polyvinylidene difluoride membrane (PVDF; Bio-Rad, Hercules, CA, USA). The membranes were blocked with $5 \%$ nonfat dry milk (Bio-Rad) in TTBS (50 mM Tris- $\mathrm{HCl}, 150 \mathrm{mM} \mathrm{NaCl}$, $0.1 \%(\mathrm{v} / \mathrm{v})$ Tween-20) for $1 \mathrm{~h}$ at room temperature and then incubated in primary antibodies diluted to $1: 1,000$ in $5 \%$ nonfat dry milk/TTBS overnight at $4^{\circ} \mathrm{C}$. The membranes were washed three times with TTBS for $15 \mathrm{~min}$ and subsequently incubated in HRP-conjugated goat anti-rabbit IgG (Dako, Glostrup, Denmark) or HRP-conjugated goat anti-mouse IgG (Dako) diluted to 1:3,000 in 5\% nonfat dry milk/TTBS for $1 \mathrm{~h}$ at room temperature. The membranes were washed as described above and developed using the ECL detection system (Amersham, Arlington Height, IL, USA).

Immunofluorescence assay. HCT116 colon cancer cells were cultured in an 8-well Lab-Tek chamber slide (Nalge Nunc International, Naperville, IL, USA), and were pretreated for $2 \mathrm{~h}$ with or without $0.5 \mathrm{mM}$ sulindac, and then treated for $24 \mathrm{~h}$ with $\mathrm{As}_{2} \mathrm{O}_{3}(1,5,10 \mu \mathrm{M})$. The slides were washed with PBS and fixed in a $4 \%$ paraformaldehyde/PBS solution for $20 \mathrm{~min}$ at room temperature. The slides were washed with PBS and then incubated in blocking solution (10\% normal goat serum, $0.3 \%$ Triton $\mathrm{X}-100,0.1 \% \mathrm{BSA} / \mathrm{PBS}$ ) for $1 \mathrm{~h}$ at room temperature. The slides were treated with the NF-кB p65 antibody which had been diluted at 1:100 in 10\% normal goat serum and $0.1 \% \mathrm{BSA} / \mathrm{PBS}$ overnight at $4^{\circ} \mathrm{C}$. After washing with $\mathrm{PBS}$, the slides were incubated at room temperature for $2 \mathrm{~h}$ with FITC-conjugated goat anti-mouse IgG which had been diluted at $1: 200$ in the $0.1 \%$ BSA/PBS (Jackson ImmunoResearch, West Grove, PA, USA). After washing with $\mathrm{PBS}$ and $\mathrm{H}_{2} \mathrm{O}$, the slides were mounted. The slides were examined under a fluorescent microscope.

\section{Results}

Sulindac synergistically enhances $\mathrm{As}_{2} \mathrm{O}_{3}$ induced cell growth inhibition. $\mathrm{As}_{2} \mathrm{O}_{3}$ is known to inhibit cell proliferation, and sulindac also causes regression of cell growth in colon cancer. The goal of this study was to investigate whether the combination of $\mathrm{As}_{2} \mathrm{O}_{3}$ and sulindac is able to work synergistically. To examine whether sulindac can enhance the effect of $\mathrm{As}_{2} \mathrm{O}_{3}$ on cell proliferation and cell death, an MTT assay was performed. $\mathrm{As}_{2} \mathrm{O}_{3}$ alone had a minimal effect in inhibiting cell growth, while the combination of $\mathrm{As}_{2} \mathrm{O}_{3}$ and sulindac resulted in about a $30-40 \%$ reduction of cell growth in a dose-dependent manner over the same time period (Fig. 1). This indicates that sulindac synergistically enhances $\mathrm{As}_{2} \mathrm{O}_{3}$ induced cytotoxicity.

Sulindac and $\mathrm{As}_{2} \mathrm{O}_{3}$ synergistically induce cell death. To clarify whether the reduction of viable cells after the combined treatment with $\mathrm{As}_{2} \mathrm{O}_{3}$ and sulindac is mediated through the induction of apoptosis, cells were stained with Wright stain solution and annexin V-FITC, and analyzed by flow cytometry. Wright staining showed that treatment with $\mathrm{As}_{2} \mathrm{O}_{3}$ and sulindac induced more apoptotic cells than treatment with $\mathrm{As}_{2} \mathrm{O}_{3}$ alone (Fig. 2). Fig. 3 shows the apoptotic effect of the combined treatment on HCT116 colon 


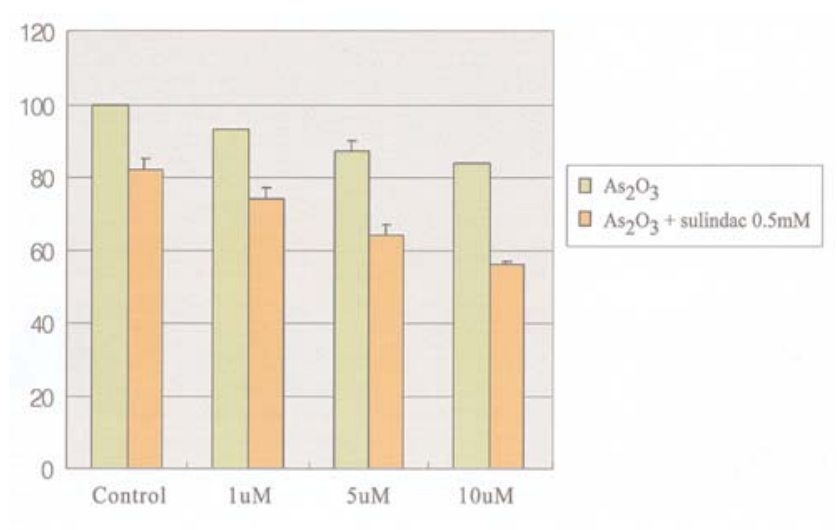

Figure 1. Effect of sulindac on arsenic trioxide-induced cytotoxicity in HCT116 colon cancer cells. Cells were treated with arsenic trioxide (1, 5, $10 \mu \mathrm{M})$ and/or sulindac $(0.5 \mathrm{mM})$. In the combination of two agents, cells were pretreated with sulindac $0.5 \mathrm{mM}$ for $2 \mathrm{~h}$ before incubation with $\mathrm{As}_{2} \mathrm{O}_{3}(1,5,10 \mu \mathrm{M})$ for $24 \mathrm{~h}$. Viability was assessed by MTT assay, and results are given as percentages of the controls. Data points show the averages for triplicate results from a representative experiment. The green control bar represents untreated HCT116 colon cancer cells. The orange control bar represents treatment with sulindac $0.5 \mathrm{mM}$ only. $\mathrm{As}_{2} \mathrm{O}_{3}$, arsenic trioxide.

(a)

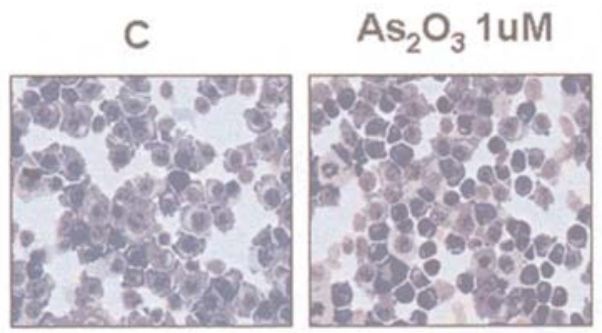

$\mathrm{As}_{2} \mathrm{O}_{3} \mathrm{5uM}$

$\mathrm{As}_{2} \mathrm{O}_{3} 10 \mathrm{uM}$
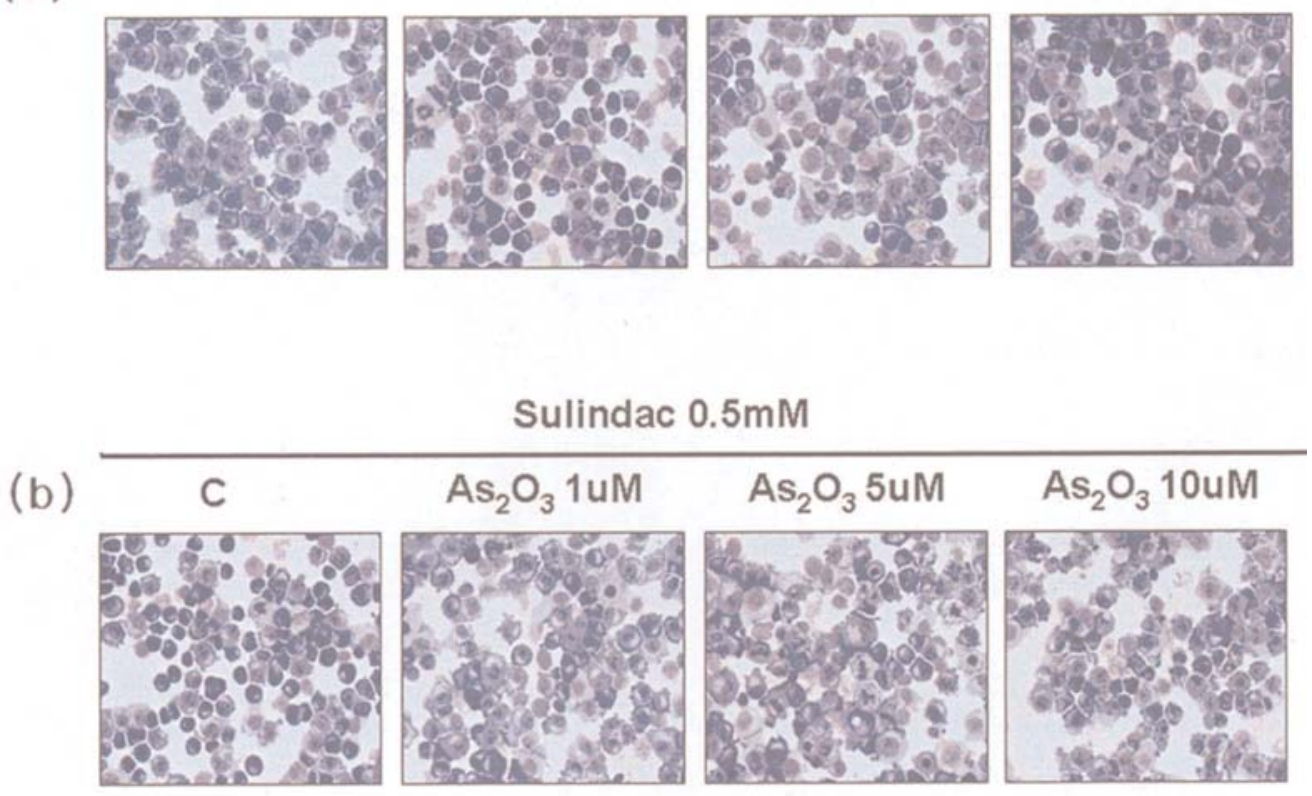

Figure 2. Effect of sulindac on arsenic trioxide-induced apoptosis in HCT116 colon cancer cells. Cells were treated with arsenic trioxide (1, 5, $10 \mu \mathrm{M})$ and/or sulindac $(0.5 \mathrm{mM})$. In the combination of the two agents, cells were pretreated with sulindac $0.5 \mathrm{mM}$ for $2 \mathrm{~h}$ before incubation with As $\mathrm{O}_{3}(1,5,10 \mu \mathrm{M})$ for $24 \mathrm{~h}$. After treatment, cells were stained with Wright stain and morphology was examined by microscopy (x100). (a) Morphological change of cells after treatment with arsenic trioxide alone. The control was untreated HCT116 colon cancer cells. (b) Morphological change of cells after exposure to arsenic trioxide and sulindac. The control was HCT116 colon cancer cells treated with sulindac $0.5 \mathrm{mM}$ only. $\mathrm{As}_{2} \mathrm{O}_{3}$, arsenic trioxide; $\mathrm{C}$, control.

cancer cells using flow cytometric analysis after annexin $\mathrm{V}$ FITC staining. The combination of $\mathrm{As}_{2} \mathrm{O}_{3} 5 \mu \mathrm{M}$ and sulindac $0.5 \mathrm{mM}$ significantly increased the percentage of apoptotic cells to $42 \%$, while $\mathrm{As}_{2} \mathrm{O}_{3} 5 \mu \mathrm{M}$ only slightly increased the percentage of apoptotic cells to $13.2 \%$. Notably, a concentration of $\mathrm{As}_{2} \mathrm{O}_{3} 10 \mu \mathrm{M}$ alone resulted in a $13.8 \%$ increase, while the combined treatment resulted in a $45 \%$ increase in apoptotic cells, which is only slightly higher when compared to those of a concentration of $\mathrm{As}_{2} \mathrm{O}_{3} 5 \mu \mathrm{M}$ (Fig. 3). These results suggest that sulindac enhances $\mathrm{As}_{2} \mathrm{O}_{3}$-induced apoptosis synergistically, and the concentration of $\mathrm{As}_{2} \mathrm{O}_{3}$ should be at least $5 \mu \mathrm{M}$ in order to induce the synergistic effect of the combination with sulindac.

Sulindac promotes $\mathrm{As}_{2} \mathrm{O}_{3}$-induced apoptosis through a caspase-8- and -3-mediated apoptotic pathway. $\mathrm{As}_{2} \mathrm{O}_{3}$ has been shown to cause cell death through activating caspases that trigger a death pathway in several types of cancer cells, including leukemic, myeloma and lung cancer cells. In order to confirm that increased apoptosis caused by the combination of $\mathrm{As}_{2} \mathrm{O}_{3}$ and sulindac was mediated by activation of caspases in the HCT116 colon cancer cells, we assessed different induction markers, such as caspase- 8 , and caspase- 3 activation by Western blot analysis. Treatment of cells with $\mathrm{As}_{2} \mathrm{O}_{3}$ alone did not activate the initiator, caspase-8, whereas treatment with $\mathrm{As}_{2} \mathrm{O}_{3}$ and sulindac resulted in activation of caspase- 8 in a dose-dependent manner (Fig. 4). This became noticeable at a concentration of $\mathrm{As}_{2} \mathrm{O}_{3} 5 \mu \mathrm{M}$ and sulindac $0.5 \mathrm{mM}$. The precursor form of caspase- 3 was cleaved to $17 \mathrm{kDa}$ after treatment with the combination of the two agents, indicating that caspase-3 was also activated by treatment with $\mathrm{As}_{2} \mathrm{O}_{3}$ and sulindac. This result suggests that the combination of $\mathrm{As}_{2} \mathrm{O}_{3}$ and sulindac promotes apoptosis by a caspase-8- and -3-mediated pathway in HCT116 colon cancer cells. 


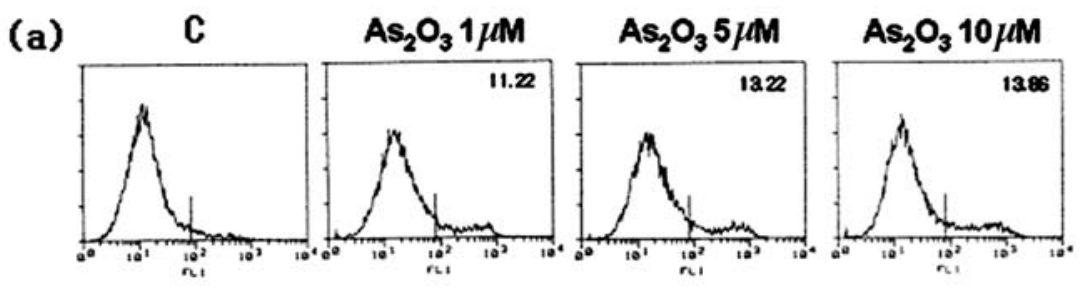

(b) Sulindac $0.5 \mathrm{mM}$

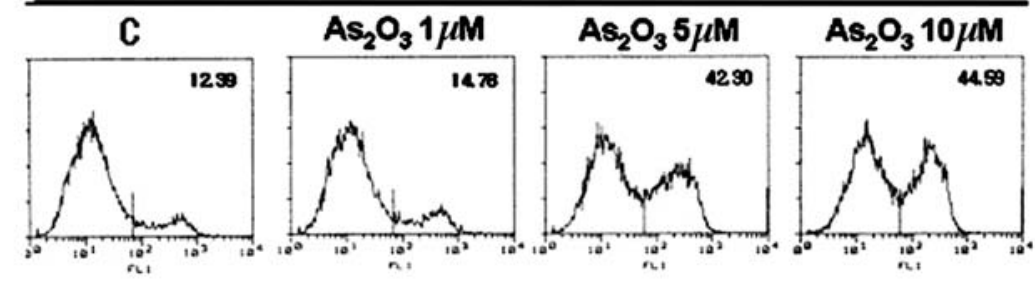

Figure 3. Effect of sulindac on arsenic trioxide-induced apoptosis in HCT116 colon cancer cells. Cells were treated with arsenic trioxide (1, 5, 10 $\mu \mathrm{M})$ and/or sulindac $(0.5 \mathrm{mM})$. In the combination of the two agents, cells were pretreated with sulindac $0.5 \mathrm{mM}$ for $2 \mathrm{~h}$ before incubation with As $\mathrm{O}_{3}(1,5,10 \mu \mathrm{M})$ for $24 \mathrm{~h}$. After treatment cells were stained with Annexin V-FITC and analyzed by flow cytometry. The values in the upper right corner illustrate the percentage of apoptotic cells. (a) Apoptotic cells after treatment with arsenic trioxide alone. The control was untreated HCT116 colon cancer cells. (b) Apoptotic cells after exposure to arsenic trioxide and sulindac. The control was $\mathrm{HCT} 116$ colon cancer cells treated with sulindac $0.5 \mathrm{mM}$ only. As $\mathrm{O}_{3}$, arsenic trioxide; $\mathrm{C}$, control.

(a)

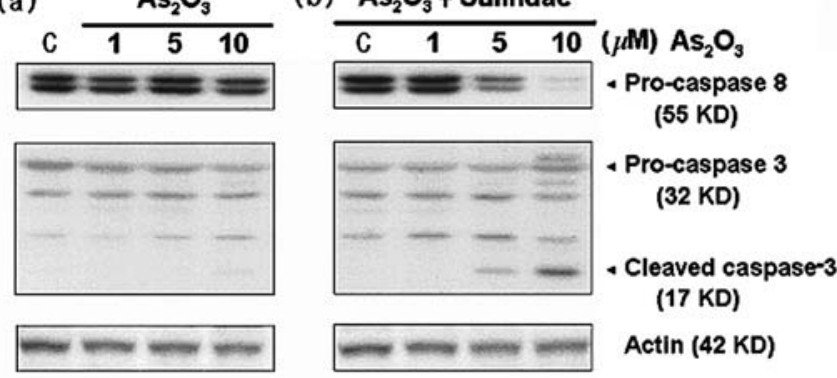

Figure 4. Effect of the combination of arsenic trioxide and sulindac on activation of caspases in HCT116 colon cancer cells. Cells were treated with arsenic trioxide $(1,5,10 \mu \mathrm{M})$ and/or sulindac $(0.5 \mathrm{mM})$. In the combination of the two agents, cells were pretreated with $0.5 \mathrm{mM}$ sulindac for $2 \mathrm{~h}$ before incubation with $\mathrm{As}_{2} \mathrm{O}_{3}(1,5,10 \mu \mathrm{M})$ for $24 \mathrm{~h}$. Equal loading was determined by actin. (a) The activation of caspases after treatment of arsenic trioxide alone. The control was untreated HCT116 colon cancer cells. (b) The activation of caspases after exposure to arsenic trioxide and sulindac. The control was HCT116 colon cancer cells treated with sulindac $0.5 \mathrm{mM}$ only. $\mathrm{As}_{2} \mathrm{O}_{3}$, arsenic trioxide; $\mathrm{C}$, control.

Combination of $\mathrm{As}_{2} \mathrm{O}_{3}$ and sulindac inhibits phosphorylation and degradation of $I \kappa B-\alpha$. It can be hypothesized that the synergistic effect of apoptosis caused by the combination of sulindac and $\mathrm{As}_{2} \mathrm{O}_{3}$ is attributable to the inhibition of NF- $\kappa \mathrm{B}$. The NF- $\mathrm{KB}$ transcription factor resides in cytosol in an inactive state, complexed with the inhibitory protein IкB. Activation occurs by phosphorylation of IкB- $\alpha$ at Ser32 and Ser36. Phosphorylation of IкB causes proteosome-mediated degra-

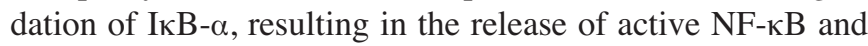
nuclear translocation of activated NF- $\kappa \mathrm{B}$. As phosphorylation of $I \kappa B-\alpha$ at Ser32 is essential for the release of active NF- $\kappa B$, phosphorylation at this site is an excellent marker of NF- $\mathrm{NB}$ activation. To ascertain whether the addition of sulindac to $\mathrm{As}_{2} \mathrm{O}_{3}$ inhibits phosphorylation of IкB- $\alpha$ and ultimately

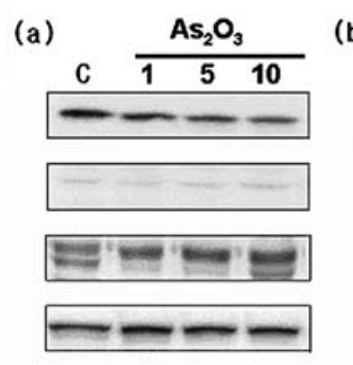

(b) $\mathrm{As}_{2} \mathrm{O}_{3}+$ Sulindac

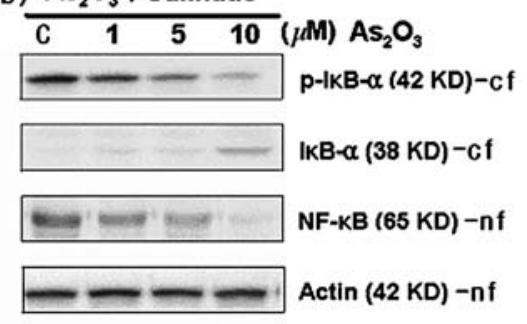

Figure 5. Effect of the combination therapy on activation of NF- $\mathrm{KB}$ in HCT116 colon cancer cells. Cells were treated with arsenic trioxide $(1,5$, $10 \mu \mathrm{M})$ and/or sulindac $(0.5 \mathrm{mM})$. In the combination of two agents, cells were pretreated with sulindac $0.5 \mathrm{mM}$ for $2 \mathrm{~h}$ before incubation with $\mathrm{As}_{2} \mathrm{O}_{3}$ $(1,5,10 \mu \mathrm{M})$ for $24 \mathrm{~h}$. IкB- $\alpha$ and NF- $\mathrm{KB}$ were measured by Western blot analysis. Equal loading was determined by actin. (a) The activation of NF$\kappa \mathrm{B}$ after treatment of arsenic trioxide alone. The control was untreated HCT116 colon cancer cells. (b) The activation of NF- $\mathrm{B}$ after exposure to arsenic trioxide and sulindac. The control was HCT116 colon cancer cells treated with sulindac $0.5 \mathrm{mM}$ only. $\mathrm{As}_{2} \mathrm{O}_{3}$, arsenic trioxide; $\mathrm{C}$, control; cf, cytosolic fraction; nf, nuclear fraction.

inhibits NF- $\mathrm{BB}$ activation, we measured the level of phospho-

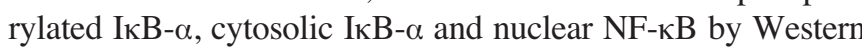
blot analysis. Fig. 5 shows that $\mathrm{As}_{2} \mathrm{O}_{3}$ alone failed to suppress the phosphorylation of $\mathrm{I} \kappa \mathrm{B}-\alpha$, whereas $\mathrm{As}_{2} \mathrm{O}_{3}$ plus sulindac suppressed the phosphorylation $(42 \mathrm{kDa})$ and degradation (38 $\mathrm{kDa})$ of IкB- $\alpha$ in a dose-dependent manner. Treatment with $\mathrm{As}_{2} \mathrm{O}_{3}$ alone activates NF-kB $(65 \mathrm{kDa})$ in a dose-dependent manner. However, the combination of the two agents can inhibit NF-кB activation. The decreased level of nuclear $\mathrm{NF}-\kappa \mathrm{B}$ was paralleled to the increased level of cytoplasmic $\mathrm{I} \kappa \mathrm{B}-\alpha$ in the combination treatment. The result was further supported by a decrease in phosphorylated I $\kappa \mathrm{B}-\alpha$ in the combination treatment. It showed that the inhibition of $N F-\kappa B$ activation began at a concentration of $\mathrm{As}_{2} \mathrm{O}_{3} 1 \mu \mathrm{M}$ 

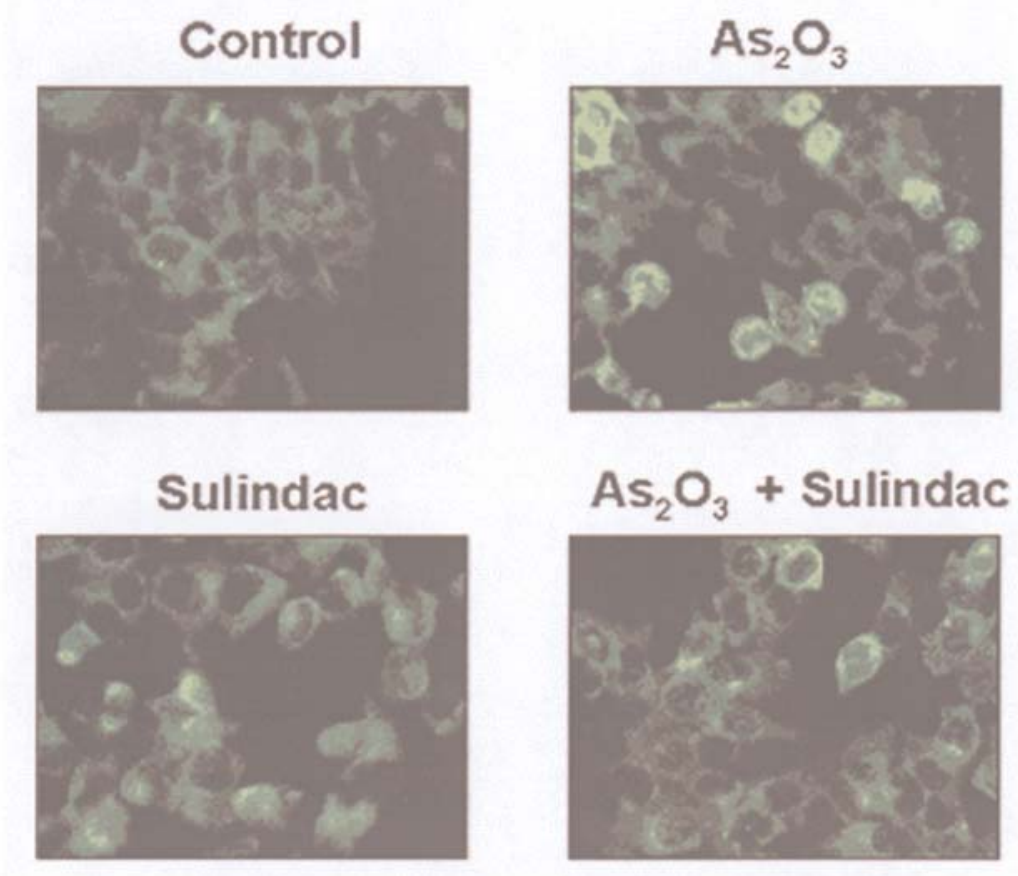

Figure 6. Sulindac inhibits nuclear translocation of NF-кB in HCT116 colon cancer cells. HCT116 colon cancer cells were cultured in an 8-well Lab-Tek chamber slide (Nalge Nunc International, Naperville, IL, USA) and pretreated for $2 \mathrm{~h}$ with or without sulindac $0.5 \mathrm{mM}$ and then treated with arsenic trioxide $(1,5,10 \mu \mathrm{M})$. The slides were stained with the NF-кB p65 antibody and FITC-conjugated goat anti-mouse IgG. The slides were examined under a fluoroscent microscope. The control was untreated HCT116 colon cancer cells. $\mathrm{As}_{2} \mathrm{O}_{3}$, arsenic trioxide; C, control.

and sulindac $0.5 \mathrm{mM}$, with a concentration of $\mathrm{As}_{2} \mathrm{O}_{3} 10 \mu \mathrm{M}$ and sulindac $0.5 \mathrm{mM}$ being able to almost completely block $\mathrm{NF}-\kappa \mathrm{B}$ activation. Surprisingly, treatment with sulindac alone slightly activates NF-кB in HCT116 colon cancer cells (Fig. 5).

Combination of $\mathrm{As}_{2} \mathrm{O}_{3}$ and sulindac inhibits translocation of activated $N F-\kappa B$ into the nucleus. To confirm that the combination of $\mathrm{As}_{2} \mathrm{O}_{3}$ and sulindac inhibits the translocation of activated NF- $\mathrm{NB}$ into the nucleus, immunofluorescence staining was performed (Fig. 6). As we expected, the combination of the two agents blocked nuclear translocation of $\mathrm{NF}-\kappa \mathrm{B}$, while $\mathrm{As}_{2} \mathrm{O}_{3}$ alone allowed some nuclear translocation. It can also be compared to treatment with sulindac alone in that it did not suppress the nuclear translocation of NF-кB. This indicates that a combination of $\mathrm{As}_{2} \mathrm{O}_{3}$ and sulindac ultimately blocks the translocation of activated NF- $\mathrm{B}$ through the inhibition of phosphorylation and degradation of IкB- $\alpha$.

\section{Discussion}

$\mathrm{As}_{2} \mathrm{O}_{3}$ has been reported to induce complete remission in patients with relapsed APL as well as newly developed APL. The use of $\mathrm{As}_{2} \mathrm{O}_{3}$ is increasing, since this agent has diverse pathways in malignant cells and multiple potential molecular targets which indicate that it could be used as a targeted cancer therapy. Via numerous pathways, $\mathrm{As}_{2} \mathrm{O}_{3}$ participates in the induction of apoptosis and differentiation, and the inhibition of angiogenesis. There are several possible mechanisms that $\mathrm{As}_{2} \mathrm{O}_{3}$ involves in apoptosis and differentiation in cancer cells. These are mediated by elevated intracellular
$\mathrm{H}_{2} \mathrm{O}_{2}$ leading to cytochrome c release and by the activation of the caspase cascade, by increased bax expression and inhibition of NF-кB $(1,6,18-20)$. Currently, many scientists are attempting to use $\mathrm{As}_{2} \mathrm{O}_{3}$ as a chemotherapeutic agent in treating solid tumors. In fact, in vitro studies with $\mathrm{As}_{2} \mathrm{O}_{3}$ of several solid tumors including lung, prostate, renal cell and colon cancer have been carried out (21-25). Researchers have studied ways of enhancing $\mathrm{As}_{2} \mathrm{O}_{3}$-induced cytotoxicity, and have tried the combination with several agents such as ATRA, imatinib, IFN- $\alpha$, vitamin $\mathrm{C}$, and doxahexanoic acid $(10,11,23)$.

Sulindac may be a good candidate for enhancing the $\mathrm{As}_{2} \mathrm{O}_{3}$ induced effect as sulindac has been demonstrated to play a role in the prevention of colon cancer from precancerous lesions $(26,27)$. Sulindac is a nonsteroidal anti-inflammatory agent that inhibits cyclooxygenase activity to block prostaglandin synthesis. Sulindac sulfide is the most active metabolite of sulindac and blocks prostaglandin synthesis by non-selective inhibition of cyclooxygenase 1 and 2 (27). However, alternative mechanisms of sulindac action other than the inhibition of prostaglandin synthesis have demonstrated that sulindac is also capable of inhibiting activation of the NF-кB pathway, PPAR $\delta$ and phosphodiesterase $(17,28,29)$. Collectively, these findings suggest that it is feasible to combine $\mathrm{As}_{2} \mathrm{O}_{3}$ and sulindac to enhance cytotoxicity that can lead to cancer cell death. There have been several studies which support the hypothesis that a combination of the two agents can work synergistically on cancer cell lines $(30,31)$. As we expected in our study, sulindac was able to enhance the $\mathrm{As}_{2} \mathrm{O}_{3}$-induced cytotoxic effect in colon cancer cells. In fact, in this study the combination of $\mathrm{As}_{2} \mathrm{O}_{3}$ and sulindac resulted in a dramatic 
reduction in cell growth as compared to treatment with $\mathrm{As}_{2} \mathrm{O}_{3}$ alone.

The question is how the combination of $\mathrm{As}_{2} \mathrm{O}_{3}$ and sulindac enhances cytotoxicity. To address this question, we assessed an apoptosis pathway that is known to be associated with $\mathrm{As}_{2} \mathrm{O}_{3}$-induced cytotoxicity. Our study showed that treatment of colon cancer cells with $\mathrm{As}_{2} \mathrm{O}_{3}$ induced apoptosis, and was markedly enhanced when used in combination with sulindac. This indicates that sulindac synergistically enhances $\mathrm{As}_{2} \mathrm{O}_{3}$-induced apoptosis. $\mathrm{As}_{2} \mathrm{O}_{3}$ exposure has been shown to activate caspases both in vitro, and in vivo $(1,32,33)$. Whether the activation of caspases by $\mathrm{As}_{2} \mathrm{O}_{3}$ is a direct or indirect effect of the agent is not clear. In clinical trials with relapsed APL patients, responses to $\mathrm{As}_{2} \mathrm{O}_{3}$ were associated with enhanced expression of proenzymes for caspase- 2 and -3 , and activation of caspase-1 and -2 (34). In another study using myeloma cells, $\mathrm{As}_{2} \mathrm{O}_{3}$ induced apoptosis via caspase-9 activation at a clinically relevant level $(2-5 \mu \mathrm{M})(35) . \mathrm{As}_{2} \mathrm{O}_{3}$ also promotes apoptosis by activating caspase- 3 in neuroblastoma cell lines and in myeloid leukemia cells $(36,37)$. Ishitsuka et al reported that exposure of an adult T-cell leukemia cell line to $\mathrm{As}_{2} \mathrm{O}_{3}$ in vitro activates caspase- 8 and -3 (38). Our study showed that enhanced apoptosis by the combination of the two agents is a result of activation of caspases. In this study, the combination of $\mathrm{As}_{2} \mathrm{O}_{3}$ and sulindac activated caspase- 8 and caspase- 3 , whereas $\mathrm{As}_{2} \mathrm{O}_{3}$ alone did not seem to activate caspase- 8 . However, the cleaved form of caspase-3 slightly increased at a concentration of $\mathrm{As}_{2} \mathrm{O}_{3}$ $10 \mu \mathrm{M}$ alone, indicating that a high dose of $\mathrm{As}_{2} \mathrm{O}_{3}(10 \mu \mathrm{M})$ activates caspase- 3 . Therefore, our study suggests that sulindac promotes $\mathrm{As}_{2} \mathrm{O}_{3}$-induced apoptosis through caspase- 8 and -3 activation. Recently, Jin et al reported that synergistic induction of apoptosis by $\mathrm{As}_{2} \mathrm{O}_{3}$ and sulindac in lung cancer cells is a result of the down-regulation of survivin, a member of the inhibitor of apoptosis protein (IAP) family (21).

$\mathrm{NF}-\kappa \mathrm{B}$ is a ubiquitously expressed transcription factor that plays a pivotal role in the expression of various inducible target genes that regulate apoptosis, among several other vital functions. It also controls cell proliferation, differentiation, and immune and inflammatory responses (39). NF-кB can be activated by many stress stimuli and in turn stimulate the transcription genes that allow resistance to apoptosis. When $\mathrm{NF}-\kappa \mathrm{B}$ is activated, it promotes the expression of several antiapoptotic genes, such as the cellular inhibitors of apoptosis $c$-IAP1 and $c$-IAP2 $(40,41)$. These genes induced by NF-кB can inhibit the activation of the caspase cascade that causes cell death. Thus, being able to block the activation of NF-кB may be a measure to enhance the cytotoxic effect of $\mathrm{As}_{2} \mathrm{O}_{3}$. In this study, we showed that sulindac enhanced $\mathrm{As}_{2} \mathrm{O}_{3}$ induced apoptosis, however it was not able to block the activation of NF- $\mathrm{KB}$ at concentrations of 1 through $10 \mu \mathrm{M}$ of $\mathrm{As}_{2} \mathrm{O}_{3}$ in HCT116 colon cancer cells, as we have seen in other studies with other cancer cell lines such as APL, and fibrosarcoma $(18,42)$. Unexpectedly, treatment with sulindac $0.5 \mathrm{mM}$ alone also was not able to inhibit either the phosphorylation of $\mathrm{I} \kappa \mathrm{B}-\alpha$, or the activation of NF- $\kappa \mathrm{B}$ in HCT116 colon cancer cells. However, a combination of $\mathrm{As}_{2} \mathrm{O}_{3}$ and sulindac was able to block the activation of $\mathrm{NF}-\mathrm{\kappa B}$ by the inhibition of the phosphorylation and the degradation of IкB- $\alpha$ in HCT116 colon cancer cells. Blocking the phosphorylation of IкB- $\alpha$ did not allow the nuclear translocation of $\mathrm{NF}-\kappa \mathrm{B}$. This study shows that sulindac in conjunction with $\mathrm{As}_{2} \mathrm{O}_{3}$ blocks NF- $\mathrm{\kappa B}$ activation, activates the caspase- 8 and -3 pathways and eventually induces apoptosis in colon cancer cells. $\mathrm{As}_{2} \mathrm{O}_{3}$ at a dose of 1-2 $\mathrm{mM}$ has been shown to have a therapeutic effect on APL cells, even in patients resistant to ATRA or conventional chemotherapy, with minimal toxicity. However, the dose and dosing regimen required for a clinical response to $\mathrm{As}_{2} \mathrm{O}_{3}$ in solid cancers has not been established yet. Clinical trials in treating hematologic and solid cancers with $\mathrm{As}_{2} \mathrm{O}_{3}$ are currently being conducted (43). These should clarify the prospects of the clinical potential for managing solid tumors with $\mathrm{As}_{2} \mathrm{O}_{3}$. According to our study, either treatment with $\mathrm{As}_{2} \mathrm{O}_{3}$ alone or treatment with sulindac alone in the therapeutic dose range was not able to induce effective apoptosis in HCT116 colon cancer cells. However, the combination of $\mathrm{As}_{2} \mathrm{O}_{3}$ and sulindac induced apoptosis mediated by the activation of the caspase- 8 and -3 pathway through blocking NF- $\kappa \mathrm{B}$ activation. A concentration of $\mathrm{As}_{2} \mathrm{O}_{3} 5 \mu \mathrm{M}$ and sulindac $0.5 \mathrm{mM}$ seems to be the optimal synergistic combination to induce apoptosis in colon cancer cells. Therefore, a combination of $\mathrm{As}_{2} \mathrm{O}_{3}$ and sulindac can result in a synergistic effect on colon cancer cells and may be useful in treating colon cancer patients.

In conclusion, we demonstrated that the combination of $\mathrm{As}_{2} \mathrm{O}_{3}$ and sulindac enhances cytotoxicity and apoptosis mediated by activation of caspase- 8 and -3 . This results from the blocking of $N F-\kappa B$ activation through the inhibition of phosphorylation and degradation of $\mathrm{I} \kappa \mathrm{B}-\alpha$. A concentration of $\mathrm{As}_{2} \mathrm{O}_{3} 5 \mu \mathrm{M}$ and sulindac $0.5 \mathrm{mM}$ can work in an effective synergistic manner on colon cancer cells. Therefore, the combination of $\mathrm{As}_{2} \mathrm{O}_{3}$ and sulindac may be useful in treating patients with colon cancer.

\section{Acknowledgements}

This study was funded in part by an Inje University Research Grant in 2003.

\section{References}

1. Miller WH, Schipper HM, Lee JS, Singer J and Waxman S: Mechanism of action of arsenic trioxide. Cancer Res 62: 3893-3909, 2002.

2. Niu C, Yan H, Sun HP, Liu JX, Gu BW, Su XY, Cao Q, Waxman S, Chen Z, Chen S, Shen ZX and Wang ZY: Treatment of de novo and relapsed acute promyelocytic leukemia patients with arsenic trioxide. Blood 92 (Suppl 1): 678a, 1998.

3. Shen ZX, Chen GQ, Ni JH, Li XS, Xiong SM, Qiu QY, Zhu J, Tang W, Sun GL, Yang Y, Chen KQ, Zhou L, Fang ZW, Wang YT, Ma J, Zhang P, Zhang TD, Chen SJ, Chen Z and Wang ZY: Use of arsenic trioxide in the treatment of acute promyelocytic leukemia (APL): clinical efficacy and pharmacokinetics in relapsed patients. Blood 89: 3354-3360, 1997

4. De The H, Chomienne C, Lanotte M, Degos L and Dejean A: The $t(15 ; 17)$ translocation of acute promyelocytic leukemia fuses the retinoic acid receptor alpha gene to a novel transcribed locus. Nature 347: 558-561, 1990.

5. Kakizuka A, Miller, Umesono K, Warrel RP, Frankel SR, Murty VV, Dmitrovsky E and Evans R: Chromosomal translocation $\mathrm{t}(15 ; 17)$ in acute promyelocytic leukemia fuses RAR alpha with a novel putative transcription factor, PML. Cell 66: 6632-6721, 1991 
6. Zhang TC, Cao EH, Li JF, Ma W and Qin JF: Induction of apoptosis and inhibition of human gastric cancer MGC-803 cell growth by arsenic trioxide. Eur J Cancer 35: 1258-1263, 1999.

7. Rojewski MT, Baldus C, Knauf W, Thiel E and Schrezenmeier H: Dual effects of arsenic trioxide $\left(\mathrm{As}_{2} \mathrm{O}_{3}\right)$ on non-acute promyelocytic leukaemia myeloid cell lines: induction of apoptosis and inhibition of proliferation. Br J Haematol 116: $555-563,2002$.

8. Seol JG, Park WH, Kim ES, Jung CW, Hyun JM, Lee YY and Kim BK: Potential role of caspase- 3 and -9 in arsenic trioxidemediated apoptosis in PCI-1 head and neck cancer cells. Int J Oncol 18: 249-255, 2001.

9. Zhang W, Ohnishi K, Shigeno K, Fujisawa S, Naito K, Nakamura S, Takeshita K, Takeshita A and Ohno R: The induction of apoptosis and cell cycle arrest by arsenic trioxide in lymphoid neoplasms. Leukemia 12: 1383-1391, 1998

10. Jing Y, Wang L, Xia L, Chen GO, Chen Z, Miller WH and Waxman S: Combined effect of all-trans retinoic acid and arsenic trioxide in acute promyelocytic leukemia in vitro and in vivo. Blood 97: 264-269, 2001.

11. Bazarbachi A, El-Sabban ME, Nasr R, Quignon F, Awaraji C, Kersual J, Dianoux L, Zermati Y, Haidar JH, Hermine O and de The H: Arsenic trioxide and interferon- $\alpha$ synergize to induce cell cycle arrest and apoptosis in human T-cell lymphotropic virus type I-transformed cells. Blood 93: 278-283, 1999.

12. Jiang XH, Wong BC, Yuen ST, Jiang SH, Cho CH, Lai KC, Lin MC, Kung HF, Lam K and Wong CY: Arsenic trioxide induces apoptosis in human gastric cancer cells through up-regulation of p53 and activation of caspase-3. Int J Cancer 91: 173-179, 2001.

13. Perkins C, Kim CN, Fang G and Bhalla KN: Arsenic induces apoptosis of multidrug-resistant human myeloid leukemia cells that express Bcr-Abl or overexpress MDR, MRP, Bcl-2, or Bcl-x $(\mathrm{L})$. Blood 95: 1014-1022, 2000.

14. Woo SH, Park IC, Park MJ, Lee SJ, Chun YJ, Lee SI, Hong SI and Rhee $\mathrm{CH}$ : Arsenic trioxide induces apoptosis through a reactive oxygen species-dependent pathway and loss of mitochondrial membrane potential in HeLa cells. Int J Oncol 21: 57-63, 2002.

15. Berman KS, Verma UN, Harburg G, Minna J, Cobb MH and Gaynor RB: Sulindac enhances tumor necrosis factor- $\alpha$ mediated apoptosis of lung cancer cell lines by inhibition of nuclear factor- $\mathrm{KB}$. Clin Cancer Res 8: 354-360, 2002.

16. Rao CV, Rivenson A, Simi B, Zang E, Kelloff G, Steele V and Reddy BS: Chemoprevention of colon carcinogenesis by sulindac, a nonsteroidal anti-inflammatory agent. Cancer Res 55: 1464-1472, 1995.

17. Yamamato $\mathrm{Y}$ and Gaynor R: Therapeutic potential of inhibition of the NF- $\mathrm{BB}$ pathway in the treatment of inflammation and cancer. J Clin Investig 107: 135-142, 2001.

18. Han S, Kim K, Hahm E, Park C, Kimbler BF, Lee SJ, Lee S, Kim WS, Jung CW, Park K, Kim J, Yoon S, Lee J and Park S: Arsenic trioxide represses constitutive activation of NF-kappaB and COX-2 expression in human acute myeloid leukemia, HL-60. J Cell Biochem 94: 695-707, 2005.

19. Mathas S, Lietz A, Janz M, Hinz M, Jundt F, Scheidereit C, Bommmert K and Dorken B: Inhibition of NF-kappaB essentially contributes to arsenic-induced apoptosis. Blood 102: 1028-1034, 2003.

20. Zheng Y, Ymaquchi H, Tian C, Lee MW, Tang H, Wang HG and Qhen Q: Arsenic trioxide $\left(\mathrm{As}_{2} \mathrm{O}_{3}\right)$ induces apoptosis through activation of $\mathrm{Bax}$ in hematopoietic cells. Oncogene 24: 3339-3347, 2005.

21. Jin H, Yoon S, Seo S, Lee H, Woo S, Yoo D, Lee S, Choe T, An S, Kwon T, Kim J, Park M, Hong S, Park I and Rhee C: Synergistic induction of apoptosis by sulindac and arsenic trioxide in human lung cancer A549 cells via reactive oxygen species-dependent down-regulation of surviving. Biochem Pharma 72: 1228-1236, 2006

22. Park WH, Cho YH, Jung CW, Park JO, Kim K, Im YH, Lee MH, Kang WK and Park K: Arsenic trioxide inhibits the growth of A498 renal cell carcinoma cells via cell cycle arrest or apoptosis. Biochem Biophy Res Commun 300: 230-235, 2003.

23. Baumgartner M, Sturlan S, Roth E, Wessner B and Bachleitner-Hoffmann T: Enhancement of arsenic trioxidemediated apoptosis using docosahexaenoic acid in arsenic trioxide-resistant solid tumor cells. Int J Cancer 112: 707-712, 2004.
24. Lu M, Xia L, Luo D, Waxman S and Jing Y: Dual effects of glutathione- $S$-transferase $\pi$ on $\mathrm{As}_{2} \mathrm{O}_{3}$ action in prostate cancer cells: enhancement of growth inhibition and inhibition of apoptosis. Oncogene 23: 3945-3952, 2004.

25. Lavagna C, Burguad J, Soldato PD and Rampal P: Antiproliferative effects of nitrosulindac on human colon adenocarcinoma cell lines. Biochem Biophy Res Commun 284: 808-816, 2001.

26. Sun BC, Zhao XL, Zhang SW, Liu YX, Wang L and Wang X: Sulindac induces apoptosis and protects against colon carcinoma in mice. World J Gastroenterol 11: 2822-2826, 2005.

27. Duggan DE: Sulindac: therapeutic implications of the prodrug/ pharmacophore equilibrium. Drug Metab Rev 12: 325-337,1981.

28. He TC, Chan TA, Vogelstein B and Kinzler KW: PPARס is an APC-regulated target of nonsteroidal anti-inflammatory drugs. Cell 99: 335-345, 1999

29. Thompson WJ, Piazza GA, Li H, Liu L, Fetter J, Zhu B, Sperl G, Ahnen D and Pamukcu R: Exisulind induction of apoptosis involves guanosine 3',5'-cyclic monophosphate phosphodiesterase inhibition, protein kinase $\mathrm{G}$ activation, and attenuated betacatenin. Cancer Res 60: 3338-3342, 2000.

30. Jiang TT, Brown SL and Kim JH: Combined effect of arsenic trioxide and sulindac sulfide in A549 human lung cancer cells in vitro. J Exp Clin 23: 259-262, 1999

31. Kim HR, Kim EJ, Yang SH, Jeong ET, Park C, Kim SJ, Youn MJ, So HS and Park R: Combination treatment with arsenic trioxide and sulindac augments their apoptotic potential in lung cancer cells through activation of caspases cascade and mitochondrial dysfunction. Int J Oncol 28: 1401-1408, 2006

32. Li X, Ding X and Adrian TE: Arsenic trioxide induces apoptosis in pancreatic cancer cells via changes in cell cycle, caspase activation, and GADD expression. Pancreas 27: 174-179, 2003.

33. Mahieux R, Pise-Masison C, Gessain A, Brady JN, Olivier R, Perret E, Misteli T and Nicot C: Arsenic trioxide induces apoptosis in human T-cell leukemia virus type 1- and type 2infected cells by a caspase-3-dependent mechanism involving Bcl-2 cleavage. Blood 98: 3762-3769, 2001.

34. Soignet S, Maslak P, Wang ZG, Jhanwar S, Calleja E, Darnashti J, Corso D, De Blasio A, Gabrilove J, Scheinberg DA, Pandolfi PP and Warrell RP: Complete remission after treatment of acute promyelocytic leukemia with arsenic trioxide. N Engl J Med 339: 1341-1348, 1998.

35. Hayashi T, Hideshima T, Akiyama M, Richardson P, Schlossman RL, Chauhan D, Munshi NC, Waxman S and Anderson KC: Arsenic trioxide inhibits growth of human multiple myeloma cells in the one marrow microenvironment. Mol Cancer Ther 1: 851-860, 2002.

36. Akao Y, Nakagawa Y and Akiyama K: Arsenic trioxide induces apoptosis in neuroblastoma cell lines through the activation of caspase 3 in vitro. FEBS Lett 455: 59-62, 1999.

37. Huang XJ, Wiernik PH, Klein RS and Gallagher RE: Arsenic trioxide induces apoptosis of myeloid leukemia cells by activation of caspases. Med Oncol 16: 58-64, 1999.

38. Ishitsuka K, Ikeda R, Suzuki S, Ohno N, Utsunomiya A, Uozumi K, Hanada S and Arima T: The inductive pathways of apoptosis and $\mathrm{G}_{1}$ phase accumulation by arsenic trioxide in an adult T-cell leukemia cell line, MT-1. Blood 94 (Suppl 1): 263b, 1999.

39. Shishodia A and Aggarwal B: Nuclear factor- $\mathrm{B}$ activation: a question of life or death. J Biochem Mol Biol 35: 28-40, 2002.

40. Mercurio F and Manning AM: Multiple signals converging on NF-кB. Curr Opin Cell Biol 11: 226-232, 1999.

41. Chu Z, McKinsey T, Liu L, Gentry J, Malim M and Ballard D: Suppression of tumor necrosis factor-induced cell death by inhibitor of apoptosis c-IAP2 is under NF-kB control. Proc Nat Acad Sci USA 94: 10057-10062, 1997.

42. Park M, Lee J, Gwak H, Park C, Lee H, Woo SH, Jin H, Han C, An S, Lee S, Chung HY, Park I, Hong S and Rhee CH: Arsenic trioxide inhibits invasion of HT1080 human fibrosarcoma cells: role of nuclear factor- $\mathrm{KB}$ and reactive oxygen species. J Cell Biochem 95: 955-969, 2005.

43. Murgo AJ: Clinical trials of arsenic trioxide in hematologic and solid tumors: overview of the National Cancer Institute cooperative research and development studies. Oncologist 6: $22-28,2001$ 